\title{
Jurnal Spasial
}

Nomor 3, Volume 5, 20118

\section{KOMPETENSI GURU DALAM MELAKSANAKAN EVALUASI PEMBELAJARAN GEOGRAFI DI SMPN KOTA PADANG}

Penulis : Nila Afryansih, Kusrini, Beatus Mendelson Laka

Sumber : Nomor 3, Volume 5, 20118

Diterbitkan Oleh : Program Studi Pendidikan Geografi, STKIP PGRI Sumatera Barat

Untuk Mengutip Artikel ini :

Afryansih, Nila. Dkk. 20118. Kompetensi Guru Dalam Melaksanakan Evaluasi Pembelajaran

Geografi di SMPN Kota Padang. Jurnal Spasial, Volume 3, Nomor 5, 20118: 50-55.

Copyright (C) 2018, Jurnal Spasial

ISSN: 2540-8933 EISSN: 2541-4380

Program Studi Pendidikan Geografi STKIP PGRI Sumatera Barat 


\title{
KOMPETENSI GURU DALAM MELAKSANAKAN EVALUASI PEMBELAJARAN GEOGRAFI DI SMPN KOTA PADANG
}

\author{
Nila Afryansih ${ }^{1}$, Kusrini $^{2}$, Beatus Mendelson Laka ${ }^{3}$ \\ 1Program Studi Pendidikan Geografi, STKIP PGRI Sumatera Barat, nilaafryansih@gmail.com \\ 2Program Studi Pendidikan Biologi, Universitas Muhammadiyah Buton, kusrinigamzaa@gmail.com \\ ${ }^{3}$ Program Studi PGSD, STKIP BIAK, lakamendelson@gmail.com
}

\section{A R T I K E L I N F 0}

Article history:

\section{Keyword:}

Kompetensi Guru

Evaluasi

\begin{abstract}
A B S T R A C T
This study aims to describe and analyze teacher competencies in conducting an evaluation of geography learning in Padang city junior high school. This study uses a qualitative method, the sample technique used is proportional stratified random sampling, which is divided into several criteria, namely first: criteria for international standard schools, namely Padang 2 Junior High School, second: criteria for national standard schools, namely Padang 12 Junior High School, and third: criteria for ordinary schools, namely SMP 18 Padang. The subject of this research is the teacher who teaches the geography of the school. Data collection techniques used in this study were observation, interviews and documentation. The results of this study are 1. the geography teacher in choosing the problem is based on the level of difficulty and distinguishing power. 2. The teacher has examined the answers of the students well and is able to classify the results. 3. The teacher is able to classify student grades and follow-up.
\end{abstract}

Penelitian ini bertujuan untuk menggambarkan dan menganalisis tentang kompetensi guru dalam melaksanakan evaluasi pembelajaran geografi di SMPN kota padang. Penelitian ini menggunakan metode kualitatif, teknik sampel yang digunakan adalah Proportioned Stratified Random Sampling atau teknik sampel berjenjang, yang dibagi kedalam beberapa kriteria, yaitu pertama: kriteria sekolah berstandar internasional yaitu SMPN 2 Padang, kedua: kriteria sekolah berstandar nasional yaitu SMPN 12 Padang, dan ketiga: kriteria sekolah biasa yaitu SMPN 18 Padang. Subjek penelitian ini adalah guru yang mengajar geografi di sekolah tersebut. Teknik pengumpulan data yang digunakan dalam penelitian ini adalah observasi, wawancara dan dokumentasi. Hasil penelitian ini adalah 1. guru geografi dalam memilih soal sudah berdasarkan tingkat kesukaran dan daya pembeda. 2. Guru sudah memeriksa jawaban siswa dengan baik dan mampu mengklasifikasikan hasil. 3. Guru sudah mampu mengklasifikasikan nilai siswa dan tindak lanjutnya.

(C)2018 Jurnal Spasial All rights reserved.

\section{PENDAHULUAN}

Sekolah merupakan lembaga pendidikan yang melakukan kegiatan belajar mengajar, membimbing, mengembangkan potensi peserta didik. Sekolah juga bisa dijadikan sebagai organisasi masyarakat yang unik yang mempunyai karakteristik tersendiri. Sebagai organisasi formal, sekolah adalah sarana dan wadah bagi sekelompok orang (kepala sekolah, guru, karyawan tata usaha dan siswa) dan sekolah juga mempunyai sarana dan prasarana yang dapat menunjang terlaksananya suatu pendidikan serta untuk mencapai tujuan yang diinginkan. Tercapai atau tidaknya tujuan sekolah sangat tergantung pada orang-orang yang tergabung dalam sekolah itu.

Guru merupakan salah satu faktor yang sangat menentukan keberhasilan pendidikan di sekolah, karena guru secara langsung berhubungan dengan peserta didik. Pengelolaan proses belajar mengajar 
harus diutamakan oleh seorang guru. Berbicara mengenai kualitas guru di dalam mengajarkan geografi, baik materi geografi umum seperti lingkungan, fisik maupun materi pemetaan, maka terlebih dahulu harus memahami apa yang dimaksud dengan geografi itu sendiri, terutama pemetaan.

Tugas seorang guru adalah sebagai pengajar dan pendidik. Sebagai pengajar guru bertugas untuk menuangkan sejumlah bahan pelajaran kepada anak didik mereka, sedangkan sebagai pendidik guru bertugas untuk membimbing dan membina anak didik agar menjadi manusia yang cakap, aktif, kreatif dan mandiri. Guru merupakan tokoh kunci dalam proses tranformasi manusia Indonesia menjadi insan pancasila yang inovatif dan kreatif. Dalam sistem persekolahan, kurikulum, tenaga non pengajar, prasarana adalah penting, tetapi tanpa guru yang bermutu, yang akan berdedikasi dan berwibawa, semua masukan lain tidak akan mempunyai arti banyak. Oleh karena itu tugas berat dari seorang guru pada dasarnya hanya dapat dilakukan oleh guru yang memiliki kompetensi pedagogik yang tinggi.

Undang-undang Nomor 14 tahun 2005 tentang Guru dan Dosen merupakan suatu ketetapan politik bahwa pendidik adalah pekerja profesional, yang berhak mendapatkan hak-hak sekaligus kewajiban profesional. Dengan itu diharapkan, pendidik dapat mengabdikan secara total pada profesinya dan dapat hidup layak dari profesi tersebut. Dalam Undangundang No. 14 tahun 2005 tentang Guru dan Dosen ditentukan bahwa; 1) Pendidik wajib memiliki kualifikasi akademik dan kompetensi pendidik sebagai agen pembelajaran, 2) Kualifikasi akademik diperoleh melalui pendidikan tinggi program sarjana (S1) atau program diploma empat (D-IV) yang sesuai dengan tugasnya sebagai guru dan S-2 untuk dosen, dan 3) Kompetensi profesi pendidik meliputi kompetensi pedagogik, kompetensi kepribadian, kompetensi profesional, dan kompetensi sosial.

Kompetensi Guru merupakan seperangkat pengetahuan, keterampilan, dan perilaku yang harus dimiliki, dihayati, dikuasai, dan diaktualisasikan oleh Guru dalam melaksanakan tugas keprofesionalan. Berdasarkan Peraturan Pemerintah (PP) Nomor 18 Tahun 2007 tentang Guru, dinyatakan bahwasanya kompetensi yang harus dimiliki oleh Guru meliputi kompetensi pedagogik, kompetensi kepribadian, kompetensi sosial, dan kompetensi profesional yang diperoleh melalui pendidikan profesi. Kompetensi Guru tersebut bersifat menyeluruh dan merupakan satu kesatuan yang satu sama lain saling berhubungan dan saling mendukung.

Kompetensi pedagogik merupakan salah satu kriteria yang harus dimiliki oleh seorang guru menurut UU No.14 tahun 2005 tentang guru dan dosen, kompetensi pedagogik adalah "kemampuan mengelola pembelajaran peserta didik" atau kemampuan pemahaman tentang peserta didik secara mendalam dan penyelenggaraan pembelajaran yang mendidik. Pemahaman tentang peserta didik meliputi pemahaman tentang psikologi perkembangan anak sedangkan Pembelajaran yang mendidik meliputi kemampuan merancang pembelajaran, mengimplementasikan pembelajaran, menilai proses dan hasil pembelajaran, dan melakukan perbaikan secara berkelanjutan.

Setiap guru sebenarnya mempunyai potensi untuk selalu meningkatkan kompetensinya, akan tetapi tidak jarang guru kurang termotivasi, rendahnya kesadaran, banyaknya beban tugas, dan minimnya biaya dan kesempatan mengikuti pendidikan lanjutan menjadi faktor penghambat bagi guru dalam meningkatkan kompetensi pedagogik yang dimilikinya. Oleh karena itu perlu dukungan dari pihak luar sebagai upaya memecahkan hambatan dalam rangka peningkatan kompetensi pedagogiknya.

Kompetensi guru tidak bisa diperoleh hanya dari jalur pendidikan keguruan saja, tetapi perlu dibentuk melalui latihan-latihan dan pengalaman yang diperoleh. Dalam melaksanakan proses pembelajaran, tidak jarang guru hanya melakukan rutinitas yang sama tanpa adanya upaya untuk meningkatkan kemampuan dan kreatifitasnya dalam mengajar. Padahal ketika guru melaksanakan proses pembelajaran, disitulah dia harus mampu menganalisa kekurangan atau kelebihan yang ada. Dengan demikian guru akan selalu belajar untuk mampu memecahkan hambatan maupun mengembangkan kelebihan yang ada dan dengan sendirinya mampu meningkatkan kompetensi pedagogik guru.

Salah satu tugas penting yang acap kali dan bahkan pada umumnya dilupakan oleh staf pengajar terutama guru diberbagai sekolah di Indonesia adalah tugas melakukan evaluasi terhadap alat pengukur yang telah digunakan untuk mengukur keberhasilan mengajar dari peserta didik. Alat pengukur yang dimaksud adalah test hasil belajar, yang sebagaimana telah kita maklumi, batang tubuhnya terdiri dari kumpulan butir-butir soal atau item test (Anas Sudijono, 2011:367).

Kriteria yang harus dimiliki guru dalam meningkatkan kompetensi pedagogik terutama dalam 
mengajarkan pemetaan antara lain memiliki kemampuan merencanakan program belajar mengajar, kemampuan melaksanakan interaksi atau mengelola proses belajar mengajar, dan kemampuan melakukan penilaian yang tepat. Kriteria ini merupakan kriteria yang didapatkan dengan berbagai cara diantaranya meningkatkan kemampuan pedagogik guru tersebut.

Berbagai upaya yang dilakukan pemerintah untuk meningkatkan kompetensi pedagogik guru memang sudah dilaksanakan, seperti adanya penataran, pendidikan lanjutan melalui program beasiswa, dan uji sertifikasi guru. Akan tetapi beberapa upaya tersebut belum menjadikan jaminan terhadap peningkatan kompetensi pedagogik seorang guru secara signifikan. Beberapa upaya tersebut perlu kiranya didukung oleh kesadaran dari diri guru itu sendiri untuk senantiasa berusaha meningkatkan kompetensi pedagogik guna mencapai tujuan pendidikan serta menghasilkan anak didik yang dapat menggunakan ilmunya baik formal, informal dan non-formal.

Dalam kompetensi pedagogik ini ada beberapa aspek yang perlu diperhatikan, diantaranya adalah penilaian dan evaluasi. Guru mampu menyelenggarakan penilaian proses dan hasil belajar secara berkesinambungan. Guru melakukan evaluasi atas efektivitas proses dan hasil belajar dan menggunakan informasi hasil penilaian dan evaluasi untuk merancang program remedial dan pengayaan. Guru mampu menggunakan hasil analisis penilaian dalam proses pembelajarannya.

Menurut Mulyasa (2007:179), penilaian proses belajar mengajar dilaksanakan untuk mengetahui keberhasilan perencanaan kegiatan belajar mengajar yang telah disusun dan dilaksanakan. Penilaian diartikan sebagai proses yang menentukan betapa baik organisasi program atau kegiatan yang dilaksanakan untuk mencapai maksud-maksud yang telah ditetapkan.

Commite dalam Yamin (2007:22) menjelaskan, evaluasi merupakan bagian yang tidak terpisahkan dari setiap upaya manusia, evaluasi yang baik akan menyebarkan pemahaman dan perbaikan pendidikan, sedangkan evaluasi yang salah akan merugikan pendidikan. Tujuan utama melaksanakan evaluasi dalam proses belajar mengajar adalah untuk mendapatkan informasi yang akurat mengenai tingkat pencapaian tujuan instruksional oleh siswa, sehingga tindak lanjut hasil belajar akan dapat diupayakan dan dilaksanakan. Dengan demikian, melaksanakan penilaian proses belajar mengajar merupakan bagian tugas guru yang harus dilaksanakan setelah kegiatan pembelajaran berlangsung dengan tujuan untuk mengetahui tingkat keberhasilan siswa mencapai tujuan pembelajaran, sehingga dapat diupayakan tindak lanjut hasil belajar siswa.

Depdiknas (2005:9) mengemukakan kompetensi penilaian belajar peserta didik, meliputi : Mampu memilih soal berdasarkan tingkat kesukaran, Mampu memilih soal berdasarkan tingkat pembeda, Mampu memperbaiki soal yang tidak valid, Mampu memeriksa jawaban, Mampu mengklasifikasi hasil-hasil penilaian, Mampu mengolah dan menganalisis hasil penilaian, Mampu membuat interpretasi kecenderungan hasil penilaian, Mampu menentukan korelasi soal berdasarkan hasil penilaian, Mampu mengidentifikasi tingkat variasi hasil penilaian, Mampu menyimpulkan dari hasil penilaian secara jelas dan logis, Mampu menyusun program tindak lanjut hasil penilaian, Mengklasifikasi kemampuan siswa, Mampu mengidentifikasi kebutuhan tindak lanjut hasil penilaian, Mampu melaksanakan tindak lanjut, Mampu mengevaluasi hasil tindak lanjut, dan Mampu menganalisis hasil evaluasi program tindak lanjut hasil penilaian.

Guru memiliki hak istimewa dalam menentukan nilai siswa. Pemikiran ini harus ditinjau ulang, karena dalam prakteknya kadang-kadang guru dengan kurang pertimbangan suka memberikan nilai jelek di ujian harian, UTS atau UAS, padahal belum melakukan usaha-usahayang tepat dalam pengajarannya. Ketika guru memberikan nilai merah, maka guru tersebut harus bertanya kepada dirinya sendiri: Sudahkah ia memberikan perhatian khusus kepada siswa yang diberi nilai merah itu? Sudah berapa kalikah ia memanggil siswa untuk diberikan strategistrategi alternatif agar berhasil dalam belajarnya? Sudah berapa jauh guru tersebut membangun kerja sama dengan siswa dan orangtuanya agar nilai siswa tersebut bagus?

Sungguh tidak adil untuk situasi di negeri ini seperti saat ini apabila seorang guru hanya mengajar menggunakan gaya mengajar yang sama untuk semua siswa, tiba-tiba di akhir semester siswa diberi nilai merah, padahal guru tersebut tidak melakukan apa-apa untuk meningkatkan kemampuan siswa tersebut, selain hanya remedial. Untuk apa minggu pertama gagal ujian, minggu kedua diadakan remedial. Padahal guru tersebut belum sempat memberikan solusi belajar kepada siswa yang gagal ujian tersebut Guru mampu menyelenggarakan penilaian proses dan hasil belajar secara berkesinambungan.

Guru melakukan evaluasi atas efektivitas proses dan hasil belajar dan menggunakan informasi 
hasil penilaian dan evaluasi untuk merancang program remedial dan pengayaan. Guru mampu menggunakan hasil analisis penilaian dalam proses pembelajarannya diantaranya Guru menyusun alat penilaian yang sesuai dengan tujuan pembelajaran untuk mencapai kompetensi tertentu seperti yang tertulis dalam RPP, Guru melaksanakan penilaian dengan berbagai teknik dan jenis penilaian, selain penilaian formal yang dilaksanakan sekolah, dan mengumumkan hasil serta implikasinya kepada peserta didik, tentang tingkat pemahaman terhadap materi pembelajaran yang telah dan akan dipelajari.

Guru menganalisis hasil penilaian untuk mengidentifikasi topik/kompetensi dasar yang sulit sehingga diketahui kekuatan dan kelemahan masingmasing peserta didik untuk keperluan remedial dan pengayaan. Guru memanfaatkan masukan dari peserta didik dan merefleksikannya untuk meningkatkan pembelajaran selanjutnya, dan dapat membuktikannya melalui catatan, jurnal pembelajaran, rancangan pembelajaran, materi tambahan, dan sebagainya. Guru memanfatkan hasil penilaian sebagai bahan penyusunan rancangan pembelajaran yang akan dilakukan selanjutnya.

Dalam melaksanakan evaluasi proses belajar mengajar tujuan utamanya adalah untuk mendapatkan informasi yang akurat mengenai tingkat pencapaian tujuan instruksional oleh siswa, sehingga tindak lanjut hasil belajar akan dapat diupayakan dan dilaksanakan. Dengan demikian, melaksanakan penilaian proses belajar mengajar merupakan bagian tugas guru yang harus dilaksanakan setelah kegiatan pembelajaran berlangsung dengan tujuan untuk mengetahui tingkat keberhasilan siswa mencapai tujuan pembelajaran, sehingga dapat diupayakan tindak lanjut hasil belajar siswa.

Tujuan dari penelitian ini adalah untuk mengetahui tentang kompetensi kompetensi guru PEMBAHASAN

Berdasarkan hasil penelitian yang dilakukan pada sekolah bahwa setiap guru yang mengajar geografi di sekolah yang diteliti dengan tiga kriteria sekolah tersebut bahwa dalam memilih soal berdasarkan tingkat kesukaran, ini dapat dilihat dari dua sisi, pertama dari jumlah penyebaran soal sulit, sedang dan mudah. Yang kedua berkaitan dengan kemampuan siswa dalam tes tersebut. Jadi, kita harus menimbang tingkat kesukaran soal yang digunakan dengan jumlah penjabaran soal. Biasanya soal yang sulit diambil sebanyak $25 \%$, sedang $50 \%$ dan mudah $25 \%$. Guru yang sudah berpengalaman mengajar dan menyusun soal- dalam melaksanakan evaluasi pembelajaran geografi di SMPN kota padang.

\section{METODOLOGI}

Metode Jenis penelitian ini adalah penelitian deskriptif dengan pendekatan kualitatif. setting penelitian ini bertempat diseluruh SMP Negeri yang ada di kota Padang. Dikarenakan penelitian ini bersifat kualitatif, maka jumlah sekolah yang dijadikan lokasi penelitian disesuaikan dengan data yang dibutuhkan. Selanjutnya untuk klasifikasi sekolah yang dijadikan setting penelitian dibagi kedalam beberapa kriteria, yaitu pertama: kriteria sekolah berstandar internasional, kedua: kriteria sekolah berstandar nasional, dan ketiga: kriteria sekolah biasa. Data sekolah didapat dari dinas pendidikan kota padang. Peneliti menentukan subjek dalam penelitian ini adalah seluruh guru mata pelajaran Geografi yang mengajar di SMP.

Jumlah guru yang menjadi subjek penelitian disesuaikan dengan kebutuhan peneliti. Berdasarkan pertimbangan ini, maka dalam pengambilan sampel (subjek penelitian) menggunakan teknik sampelberjenjang (Proportioned Stratified Random Sampling) yaitu pemilihan sampel berdasarkan pada karakteristik tertentu secara berjenjang. Pertimbangan sampling dalam hal ini dimaksudkan untuk menjaring sebanyak mungkin informasi yang dikembangkan dan dianalisis untuk generalisasi. Tujuannya adalah untuk merinci kekhususan yang ada ke dalam ramuan konteks yang unik dan menjadi dasar dari rancangan dan teori yang muncul. Teknik pengumpulan data yang digunakan dalam penelitian ini adalah observasi, wawancara dan dokumentasi. Teknik keabsahan data pada penelitian ini adalah perpanjangan keikutsertaan, ketekunan pengamatan, serta triangulasi. Dengan analisa datanya yaitu reduksi data, interpretasi data dan pengambilan keputusan.

soal test, juga masih sukar menyadari bahwa testnya masih belum sempurna. Oleh karna itu cara yang paling baik adalah secara jujur melihat hasil yang diperoleh oleh siswa.

Secara teoritis, siswa dalam satu kelas merupakan populasi atau kelompok yang keadaannya heterogen. Dengan demikian maka apabila dikenal sebuah testakan tercermin hasilnya dalam suatu kurva normal. Sebagian besar siswa berada di daerah sedang, sebagian kecil berada di bagian kiri, dan sebagian kecil yang lain berada di bagian kanan kurva. Apabila keadaan setelah hasil tes dianalisis tidak seperti yang 
diharapkan dalam kurva normal, maka tentu ada apaapanya dengan soal test tersebut (Daryanto, 2008:176).

Dalam hal ini Arikunto menjelaskan bahwa, "Soal yang baik adalah soal yang tidak terlalu mudah dan tidak terlalu sukar, soal yang mudah tidak merangsang siswa untuk berusaha dan soal yang sukar membuat siswa putus asa" (Arikunto, Suharsimi, 2013:222). Menurut pendapat Arikunto (2012:225) Soal yang dikatakan mudah apabila lebih dari $70 \%$ peserta tes yang dapat menjawab dengan benar soal tersebut dengan indeks kesukaran 0,71 - 1,00. Daya pembeda soal adalah suatu kemampuan soal dapat membedakan siswa yang berkemampuan tinggi dan siswa berkemampuan rendah. Untuk mengetahui daya pembeda soal maka perlu mengelompokkan siswa yang berkemampuan tinggi (upper group) dan siswa yang berkemampuan rendah (lower group). Setelah dikelompokkan upper dan lower group maka dapat dihitung jumlah benar siswa yang berkemampuan tinggi dan berkemampuan rendah pada setiap soal. Dengan menghitung indeks daya beda soal maka dapat diambil keputusan apakah soal tersebut memiliki kemampuan untuk membedakan peserta tes yang berkemampuan upper atau lower. (Yunita 2018)

Untuk mendapatkan tes yang baik dapat dilakukan dengan cara mengukur tingkat kualitas soaltest. Hal ini perlu dilakukan untuk mengetahui kelemahan-kelemahan pada soal test tersebut. Dengan mengukur kualitas soal/tes yang dapat diketahui tingkat kesukaran, validitas, reliabilitas dan daya pembeda, sehingga guru dapat melakukan perbaikan pada soal yang dibuat. Guru bidang studi geografi juga mengatakan bahwa terdapat banyaknya nilai yang diperoleh siswa dari hasil test tidak mencapai Ketuntasan Kredit Minimum (KKM) yang telah di tetapkan oleh guru. (Yuslita dkk 2016)

Dalam memeriksa jawaban, guru-guru sudah sangat biasa dalam hal ini karena sebelum membuat soal guru sudah mempunyai jawaban kunci dari soal tersebut. Setiap soal yang diperiksa oleh selalu mempunyai pertimbangan dari hasil jawaban siswa tersebut. Setelah itu guru baru bisa mengklasifikasikan hasil-hasil skor siswa tersebut. Setelah diklasifikasikan hasil tersebut guru mampu mengolah dan menganalisis hasil penilaiannya. Guru menganalisis nilai berdasarkan KKM juga. Apabila ada siswa yang dibawah KKM maka harus dilakukan pengayaan terhadap siswa tersebut.

Hasil evaluasi siswa merupakan dasar untuk memberikan nilai seorang siswa setelah melalui proses pemeriksaan hasil evaluasi dan analisis. Melalui hasil analisis tersebut ibu juga membuat kecenderungan hasil belajar masing-masing kelas, sehingga pada masa mendatang dapat dijadikan pedoman untuk melakukan evaluasi. Tindak lanjut yang ibu lakukan dari hasil evaluasi biasanya memberikan program pengayaan dan kembali melakukan evaluasi lanjutan. Dalam interpretasikecenderungan hasil penilaian Ibu sebagai seorang guru mata pelajaran geografi berpedoman kepada tiga aspek yaitu kognitif, afektif dan psikomotor siswa. Karena kecenderungan hasil penilaian itu menjurus kepada tiga aspek tersebut. Dengan berpedoman kepada tiga aspek tadi ibu telah dapat menafsirkan tentang siswa yang berprestasi tinggi, sedang dan rendah.

Pelaksanaan evaluasi pembelajaran, terutama untuk mata pelajaran IPS terpadu/geografi, disesuaikan dengan karakteristik mata pelajaran tersebut. Pendapat Mulyasa (2007) mengatakan evaluasi merupakan pengukuran ketercapaian program pendidikan, perencanaan suatu program substansi pendidikan termasuk kurikulum dan pelaksanaannya, pengadaan dan peningkatan kemampuan guru, pengelolaan pendidikan dan reformasi pendidikan secara keseluruhan. Pada kurikulum berbasis kompetensi, komponen penilaiannya dikenal dengan penilaian berbasis kelas. Didalamnya terdapat proses pengumpulan, pelaporan, dan penggunaan informasi tentang belajar siswa yang diperoleh melalui pengukuran untuk menganalisis atau menjelaskan unjuk kerja atau prestasi siswa dalam mengerjakan tugas-tugas terkait. Proses penilaian mencakup pengumpulan sejumlah bukti-bukti yang menunjukkan pencapaian hasil belajar siswa. Dengan adanya proses evaluasi maka seorang guru dapat mengetahui berhasil tidaknya ia memberikan ilmu atau pengetahuan kepada muridnya dan seorang guru juga dapat mengetahui dimana kekurangannya saat mentransferkan ilmunya saat proses pembelajaran berlangsung.

\section{PENUTUP}

Kompetensi guru dalam melaksanakan evaluasi pembelajaran geografi di SMPN Kota Padang dilihat dari pertama, Guru membuat soal sudah baik. Berdasarkan hasil wawancara dengan guru, kepala sekolah serta pengawas sekolah, bahwa guru geografi dalam memilih soal sudah berdasarkan tingkat kesukaran dan daya pembeda. Kedua, Guru sudah memeriksa jawaban siswa dengan baik dan mampu mengklasifikasikan hasil nilai siswa tersebut. Ketiga, Guru sudah mampu mengklasifikasikan nilai siswa dan melakukan tindak lanjutnya terhadap siswa tersebut 


\section{DAFTAR PUSTAKA}

Arikunto, Suharsimi. 2013. Dasar-Dasar Evaluasi Pendidikan. Jakarta: Bumi Aksara. Arikunto, Suhaimi. 2012. Dasar-Dasar Evaluasi Pendidikan Edisi 2. Jakarta: PT. Bumi Aksara.

Depdiknas, 2006. Peraturan Menteri Pendidikan Nasional Indonesia Nomor 22, Jakarta: Depdiknas

Heppi Yuslita, dkk. Analisis Tingkat Kesukaran Soal Dan Daya Pembeda Soal Mata Pelajaran Sejarah Kelas Xi Semester Ganjil Di Sma Negeri 5

Banda Aceh Tahun Pelajaran 2015-2016. Jurnal Ilmiah Mahasiswa Pendidikan Sejarah Volume 1, Nomor 1, Oktober 2016, hal. 131-138 Mulyasa, 2007. Standar Kompetensi dan Sertifikasi Gur. JakartaL Remaja Rosdakarya

Sudijono, Anas. 2011. Pengantar Evaluasi Pendidikan. Jakarta: Rajawali Pers.

Yamin, Martinis. 2007. Profesionalisasi Guru dan Implementasi KTSP. Jakarta: Gaung Persada Press

Yunita, Fitri Indah. Analisis Tingkat Kesukaran Dan Daya Pembeda Soal Ujian Tengah Semester Ganjil Bahasa Indonesia Smpit Al-Madinah Tanjungpinang Kelas Vii Tahun Pelajaran 2017/2018 